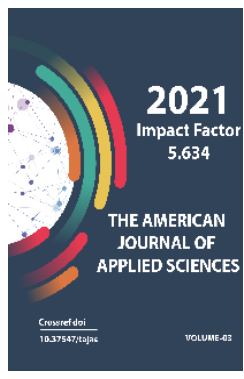

\title{
Prospects For The Application Of Digital Technologies In The Oil And Gas Industry
}

Tilakov Ismoiljon Usmonovich

Mubarak Gas Processing Plant Head Of Labor Relations Department, Uzbekistan

\section{Journal Website:}

http://theamericanjour

nals.com/index.php/taj

as

Copyright: Original content from this work may be used under the terms of the creative commons attributes 4.0 licence.

\section{ABSTRACT}

Advanced foreign experience shows that the development of the oil and gas sector based on digital technologies is a prerequisite for ensuring its stable development.

The article substantiates the possibilities for the development of the oil and gas industry of the Republic of Uzbekistan on the basis of digital technologies.

\section{KEYWORDS}

Digital technology, digital economy, oil and gas, information technology, communication, internet, consumption, income.

\section{INTRODUCTION}

The Digital Uzbekistan-2030 Strategy combines programs for the introduction of modern information technologies in industrial enterprises with programs for technological re-equipment of these enterprises, ensuring automation and management of all stages of enterprise supply, as well as reducing logistics and procurement costs, introduction of modern information systems and software. Improving the quality of products and services, reducing their cost, production downtime, increasing the transparency of financial and economic activities are recognized as priorities for the development of the digital economy [1]. This, in turn, creates the need to develop enterprises in the real sector of the economy, including the oil and gas industry on the basis of digital technologies. 
The oil and gas industry in the Republic of Uzbekistan is Uzbekneftegaz. The company is a natural monopoly, established by the Decree of the President of the Republic of Uzbekistan dated June 30, 2017 No PP-3107 "On measures to improve the management system of the oil and gas industry."

\section{Table 1}

\section{Balance sheet of Uzbekneftegaz JSC, 2019 As of December 31 [2]}

\begin{tabular}{|c|c|}
\hline \multicolumn{1}{|c|}{ Indicators } & Percent \\
\hline The share of current assets in total assets & 82,3 \\
\hline The share of long-term assets in total assets & 66,3 \\
\hline The share of liabilities in total liabilities & 33,7 \\
\hline The share of capital in total liabilities & 30 companis \\
\hline
\end{tabular}

According to Table 1, long-term assets account for the largest share in the total assets of Uzbekneftegaz.

Table 1 shows that liabilities have a relatively high share in the total liabilities of Uzbekneftegaz.

At present, Uzbekneftegaz JSC is a unified two-tier joint-stock company.

Today, Uzbekneftegaz JSC is a joint-stock company with all oil and gas industries, 123 oil and gas fields and 50,000 employees.

In developed countries and in a number of developing countries such as China and Russia, the application of digital technologies in the activities of oil and gas companies has become more active since 2000 . Leaders of companies that are leaders in the oil and gas market have come to the conclusion that the introduction of digital technologies will provide a significant advantage in the competition. As a result, major oil companies have introduced digital technologies:

* "Smart" wells - Smart Wells (Schlumberger);

* "Smart" operations - Smart Operations (Petoro);

* "Integrated" operations - Integrated Operations (Statoil, OLF);

* "Electronic" management - eOperations (North Hydro);

* "Real-time management" - Real Time Operations (Halliburton);

* “Integrated Asset Management Model" Integrated Asset Operation Model (IAOM), ADCO;

* "Smart mining" - Smart Field (Shell) [3].

The use of intelligent technology in any complex system allows you to independently regulate and optimize a large number of internal parameters of this system. The application of intelligent technologies in the 
oil and gas industry will allow to achieve the following results:

- Increase the efficiency of well operation;

- Reduction of operating costs;

- Increase in oil and gas production [4].

According to SaudiAramco, an oil company in Saudi Arabia, the use of plastic nanorobots in oil fields, which are in the final stages of development, will increase the oil recovery factor to 60-70 percent. According to CERA, the use of intelligent technologies can improve the development of oil fields by $2-7 \%$, reducing the costs associated with oil production by $25 \%[5]$.

Significant changes in the digitization of the oil industry have been observed in Norway. A few years ago, the Norwegian government set oil companies the task of extracting at least 50 percent of the geological reserves of oil. In order to accomplish this task, with the oil return ratio at 35 percent, oil companies needed to increase oil recovery through the use of new technologies. Then the Norwegian oil company Statoil together with the oil company Teradata decided to use the technology "Big Data".

In our opinion, it is expedient to use the following digital technologies in the oil and gas industry of the Republic of Uzbekistan:

\section{Big Data Technology.}

This digital technology is a technology that allows the processing of very large amounts of data at high speed and accuracy.

Three V:
* Volume

*Velocity

* Variety

\section{Artificial intelligence technology}

This technology is a technology that teaches computers to think like humans.

Artificial intelligence receives data from a variety of sources (computer science, mathematics, linguistics, psychology, biology, mechanical engineering) and makes decisions based on the processing of large amounts of data.

\section{Cloud computing technology}

This technology is a technology of data processing in a distributed manner, in which computer resources and power are provided to the user as an Internet service.

The user uses the service separately (udalenno).

Cloud services:

* Mail: gmail, hotmail;

* Work with documents separately:

Google Documents, Office Web Apps;

* Data storage: Google Drive, OneDrive, Dropbox;

* Image editing: Figma;

* Online store of applications:

Google Play, App Store and Microsoft Store. 
Digital technologies make it cheaper, faster and easier to solve large-scale operations in the oil and gas industry without intermediaries.

Digital technologies not only reduce the cost of services, but also lead to the emergence of new technologies. For example, crowdfunding and crowdsourcing can be considered as new economic technologies.

Crowdfunding (English srowd funding) is a collective partnership of people in which people voluntarily pool their money or other resources. These funds will be used to finance various forms of activities, including startup companies and small businesses, to invest for profit.

\section{REFERENCES}

1. Decree of the President of the Republic of Uzbekistan dated October 5, 2020 No PF6079 "On approval of the Strategy" Digital Uzbekistan-2030 "and measures for its effective implementation" // National Database of Legislation, 06.10.2020, 06 / 20/6079/1349; 02.04.2021, 06/21/6198/0269.

2. Statement of financial position. https: ung.uz.

3. Tcharo Honore, Vorobiev A.E., Vorobiev K.A. Digitalization of the oil industry: basic approaches and justification of "intelligent" technologies // Bulletin of Eurasian Science, 2018 No2, https://esj.today/PDF/88NZVN218.pdf.

4. Zhdanyuk A.B., Cherepovitsyn A.E. Assessment of the possibility of using intelligent technologies by oil and gas companies // SPbPU Science Week: proceedings of a scientific conference with international participation. Institute of Industrial Management, Economics and Trade. Part 1. - St. Petersburg: Publishing house of Polytekhi, University, 2017. P. 3335.

5. Stepanets L.Yu., Akopyan E.A. Analysis of the development and effectiveness of the implementation of digitalization in the oil and gas industry // Innovative Science. Moscow, 2018. - No. 7-8. - S. 69-72. 